\title{
Ceramide accumulation precedes caspase-dependent apoptosis in CHP-100 neuroepithelioma cells exposed to the protein phosphatase inhibitor okadaic acid
}

\author{
Angelo Spinedi ${ }^{\star, 1}$, Sabrina Di Bartolomeo ${ }^{1}$, \\ Federica Di Sano ${ }^{1}$, Carlo Rodolfo', \\ Arianna Ambrosino ${ }^{1}$ and Mauro Piacentini ${ }^{2}$ \\ 1 Department of Biology, University of Rome 'Tor Vergata', Italy \\ 2 Department of Environmental Sciences, 'Tuscia' University, Viterbo, and \\ Laboratory of E.M. and Cell Biology IRCCS 'L. Spallanzani', Rome, Italy \\ * corresponding author: Angelo Spinedi, Department of Biology, University of \\ Rome 'Tor Vergata', Via della Ricerca Scientifica 00133 Rome, Italy. \\ tel: +39-6-72594370; fax: +39-6-2023500; e-mail: spinedi@uniroma2.it
}

Received 5.2.99; revised 12.4.99; accepted 22.04.99

Edited by P. Cohen

\begin{abstract}
The protein phosphatase inhibitor okadaic acid (OA) dosedependently induced apoptosis in CHP-100 neuroepithelioma cells when administered for $24 \mathrm{~h}$ at concentrations ranging from 10-100 nM. Apoptosis was largely, albeit not completely, dependent on cystein protease (caspase) activation. CPP32 processing and poly(ADP-ribose) polymerase (PARP) cleavage started to be observed only at $20 \mathrm{nM} \mathrm{OA}$; moreover, the caspase inhibitor Z-Val-Ala-DL-Asp-fluoromethylketone (Z-VAD.fmk) $(100 \mu \mathrm{M})$ had negligible effect on apoptosis induced by $10 \mathrm{nM} \mathrm{OA}$, but rescued from death an increasing cell fraction as $O A$ concentration was raised from $20-100 \mathrm{nM}$. Cell treatment for $24 \mathrm{~h}$ with $O A$ induced ceramide accumulation; the phenomenon started to be evident at $20 \mathrm{nM} O A$ and reached its maximum at 50-100 nM OA. In cells exposed to $50 \mathrm{nM}$ OA, ceramide was already elevated by $5 \mathrm{~h}$; at this time, however, PARP cleavage and apoptosis were not yet observed. Z-VAD.fmk (100 $\mu \mathrm{M})$ had no effect on ceramide elevation induced by $50 \mathrm{nM} \mathrm{OA}$ within $5 \mathrm{~h}$, but markedly reduced ceramide accumulation as the incubation was prolonged to $24 \mathrm{~h}$. The latter phenomenon was accompanied by elevation of glucosylceramide levels, thus suggesting that a caspase-dependent reduction of glucosylceramide synthesis might contribute to late ceramide accumulation. Shortchain ceramide $(30 \mu \mathrm{M})$ induced apoptosis in CHP-100 cells and its effect was additive with that evoked by $O A(10-20 \mathrm{nM})$. These results suggest that ceramide generation might be an important mechanism through which sustained protein phosphatase inhibition induces caspase activation and apoptosis in CHP-100 cells.
\end{abstract}

Keywords: apoptosis; okadaic acid; ceramide; caspases; neuroepithelioma
Abbreviations: caspase, cystein protease; $\mathrm{C}_{6}-\mathrm{Cer}, \mathrm{N}$-hexanoylsphingosine; HPTLC, high-performance thin-layer chromatography; OA, okadaic acid; PARP, poly (ADP-ribose) polymerase; PP, protein phosphatase; Z-VAD.fmk, Z-Val-Ala-DL-Asp-fluoromethylketone

\section{Introduction}

Sustained inhibition of serine-threonine phosphatases (PPs) has been shown to induce apoptosis in a variety of cell systems. ${ }^{1-7}$ There is evidence that multiple pathways activated by PP inhibition may converge to elicit the apoptotic response. In various instances, apoptosis induced by okadaic acid (OA), a potent inhibitor of PP type $2 \mathrm{~A}$ and PP type $1,{ }^{8}$ has been shown to associate with cell cycle deregulation leading to abortive mitosis, ${ }^{2,7,9}$ a view consistent with the notion that PPs can modulate the expression and/or the activity of various proteins that ensure proper progression through the replicative cycle. ${ }^{8,10} \mathrm{PP}$ inhibition, on the other hand, has also been shown to modulate the expression of proteins involved in apoptosis control. In HL60 cells, for instance, OA-induced apoptosis is preceded by downregulation of the anti-apoptotic protein $\mathrm{Bcl}-2$, due to destabilization of its transcript; ${ }^{11}$ moreover, in MCF-7 and lens epithelial cells, OA-induced apoptosis associates with enhanced expression of p53 and bax, two pro-apoptotic genes. ${ }^{3,6}$ A role for cystein proteases (caspases) in apoptosis induced by sustained PP inhibition has also been reported; in particular, prolonged exposure of $\mathrm{ML}-1$ leukemia cells to the PP inhibitor calyculin $A$ has been shown to result in caspase activation and cell death. ${ }^{12}$ Ceramide (N-acyl-erythro-sphingosine) is a lipid mediator generated by neosynthesis or sphingomyelin hydrolysis in response to cell exposure to a variety of stimuli, including receptor ligation, drug treatment, irradiation and environmental stress (reviewed by Hannun ${ }^{13}$ and Mathias et al. ${ }^{14}$ ). A large body of evidence suggests that ceramide generation is a key event leading to apoptosis through mechanisms that may involve caspase activation; ${ }^{13,14}$ in this respect, we have previously demonstrated that administration of short-chain ceramide induces caspasedependent apoptosis in CHP-100 human neuroepithelioma cells. ${ }^{15}$ Presently, it is unknown whether sustained PP inhibition leads to ceramide generation. Herein we report that apoptosis induced by $\mathrm{OA}$ in $\mathrm{CHP}-100$ cells is largely, albeit not completely, dependent on caspase activation and that ceramide accumulation is selectively associated with caspase-dependent apoptosis. 


\section{Results \\ OA-induced apoptosis is largely but not entirely caspase-mediated}

CHP-100 cells exposed for $24 \mathrm{~h}$ to nanomolar concentrations of $O A$ underwent rounding, detachment from the substrate and, eventually, apoptosis. As assessed by flow cytometric analysis, the appearance of a hypodiploid population started to be observed around $10 \mathrm{nM} \mathrm{OA}$ and was fairly maximal at 50-100 nM OA (Figure 1); apoptosis occurrence was confirmed by Hoechst staining, showing outstanding chromatin condensation and progressive enhancement of nuclear fragmentation as the inhibitor concentration was raised from 10-100 nM (not shown). The possible involvement of caspase activation in apoptosis was initially studied by monitoring processing of the CPP32 proenzyme and cleavage of the endogenous caspase substrate poly (ADPribose) polymerase (PARP), ${ }^{16}$ in cells incubated for $24 \mathrm{~h}$ with different $O A$ concentrations. As shown in Figure 2 (upper panel), substantial accumulation of CPP32 low MW fragments started to be observed in cells treated with $20 \mathrm{nM} O A$; in the presence of $100 \mathrm{nM}$ OA CPP32 processing was fairly maximal, as indicated by the marked downregulation of the $32 \mathrm{kDa}$ proenzyme. PARP cleavage fairly followed the kinetics of CPP32 processing; as shown in Figure 2 (lower panel), accumulation of the $85 \mathrm{kDa}$ PARP cleavage product started to be observed at $20 \mathrm{nM} \mathrm{OA}$, whereas incubation with $100 \mathrm{nM}$ OA led to disappearance of the $116 \mathrm{kDa}$ native form of the protein. We further investigated whether caspase inhibition resulted in prevention of OA-induced apoptosis; this issue was of special relevance for cell death evoked by $10 \mathrm{nM}$ $\mathrm{OA}$, since, at this concentration, neither PARP cleavage nor CPP32 processing were observed. Figure 1 shows that the caspase inhibitor Z-Val-Ala-DL-Asp-fluoromethylketone (Z.VAD.fmk) $(50 \mu \mathrm{M})$ had negligible effect in preventing apoptosis induced by cell incubation for $24 \mathrm{~h}$ with $10 \mathrm{nM}$

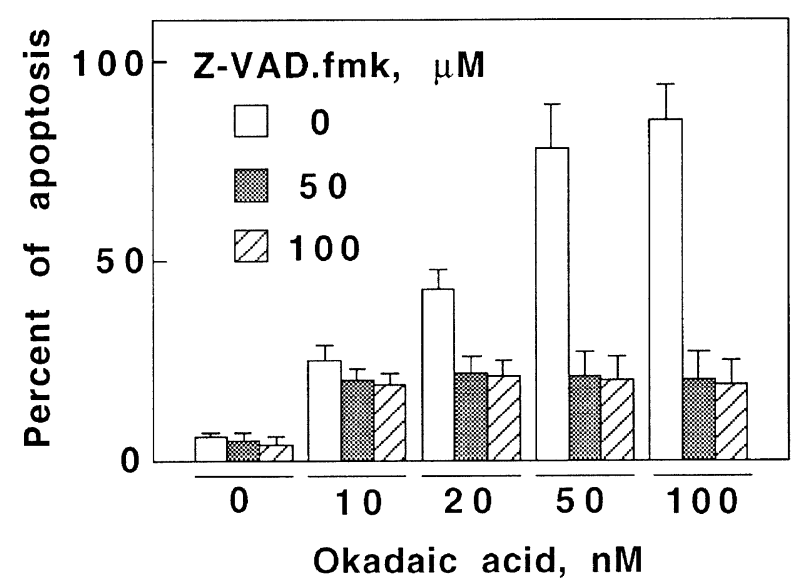

Figure 1 Apoptosis induced by $\mathrm{OA}$ in $\mathrm{CHP}-100$ cells is largely, but not completely, dependent on caspase activation. CHP-100 cells were preincubated for $1 \mathrm{~h}$ with vehicle or Z-VAD.fmk $(50 \mu \mathrm{M}$ or $100 \mu \mathrm{M})$ prior to addition of $\mathrm{OA}$ at the indicated concentrations. After $24 \mathrm{~h}$ cells were harvested and processed for apoptosis determination by flow cytometric analysis, as described in the text. Results are means + S.D. of four different experiments
OA; however, as OA concentration was raised above $10 \mathrm{nM}$, an increasing cell fraction was rescued from death. Notably, increasing Z-VAD.fmk concentration to $100 \mu \mathrm{M}$ had no further effect on apoptosis prevention.

OA evokes ceramide accumulation: insensitivity to fumonisin $B_{1}$ and relationship to apoptosis and caspase activation

We investigated whether OA treatment induced elevation of endogenous ceramide levels in the cell system under study. We have previously reported that in unstimulated CHP-100 cells ceramide mass amounts to about $3 \mathrm{pmol} / \mathrm{nmol}$ of lipid phosphate and that changes of ceramide mass can reliably be monitored by radiometric analysis, after cell labeling to equilibrium with $\left[{ }^{14} \mathrm{C}\right]$-palmitate. ${ }^{17}$ Therefore, $\left[{ }^{14} \mathrm{C}\right]$-palmitatelabeled cells were exposed for $24 \mathrm{~h}$ to different OA concentrations and radioactivity accumulation in ceramide monitored. Figure 3 shows that OA started to induce ceramide elevation at concentrations higher than $10 \mathrm{nM}$; at $50-100 \mathrm{nM}$ $\mathrm{OA}$, when apoptosis was maximal, ceramide levels reached $230-250 \%$ of those observed in untreated cells. Incidentally, after administration of $10 \mathrm{nM} \mathrm{OA}$, ceramide accumulation was not detected even at times shorter than $24 \mathrm{~h}$. Fumonisin $\mathrm{B}_{1}$, a fungal toxin that inhibits ceramide synthase has been successfully used to block ceramide elevation due to neosynthesis and to assess the relevance of the phenomen-
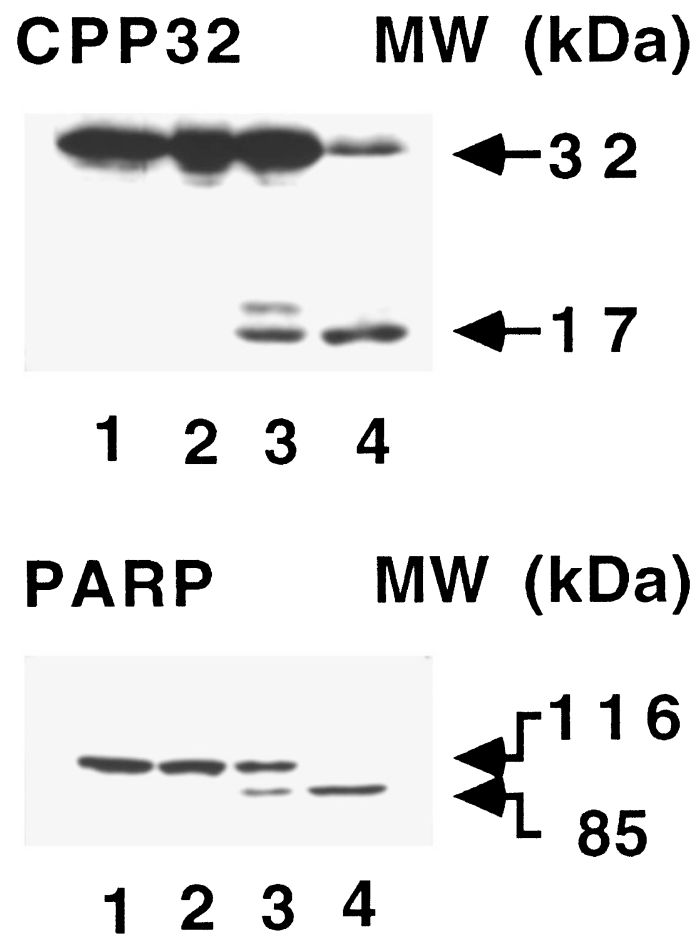

Figure $2 \mathrm{OA}$ induces CPP32 processing and PARP cleavage. Cells were incubated for $24 \mathrm{~h}$ with vehicle (lane 1) or $\mathrm{OA}$ at the concentration of $10 \mathrm{nM}$ (lane 2), $20 \mathrm{nM}$ (lane 3) or $100 \mathrm{nM}$ (lane 4). Samples were then lysed and analyzed by Western blotting for CPP32 (upper panel) or PARP (lower panel), as described in the text 
on in apoptosis induction. ${ }^{18-20}$ Figure 4 shows that fumonisin $\mathrm{B}_{1}(25 \mu \mathrm{M})$, administered for $24 \mathrm{~h}$ to $\left[{ }^{14} \mathrm{C}\right]$-palmitate-labeled CHP-100 cells slightly reduced basal ceramide levels; however, when the toxin was administered in combination with $50 \mathrm{nM} \mathrm{OA}$, it was ineffective in suppressing ceramide elevation. Similar results were obtained when fumonisin $B_{1}$ concentration was raised to $50 \mu \mathrm{M}$; moreover, fumonisin $\mathrm{B}_{1}$ had no effect on OA-induced apoptosis (not shown). It has been reported that sphingomyelinase-mediated ceramide

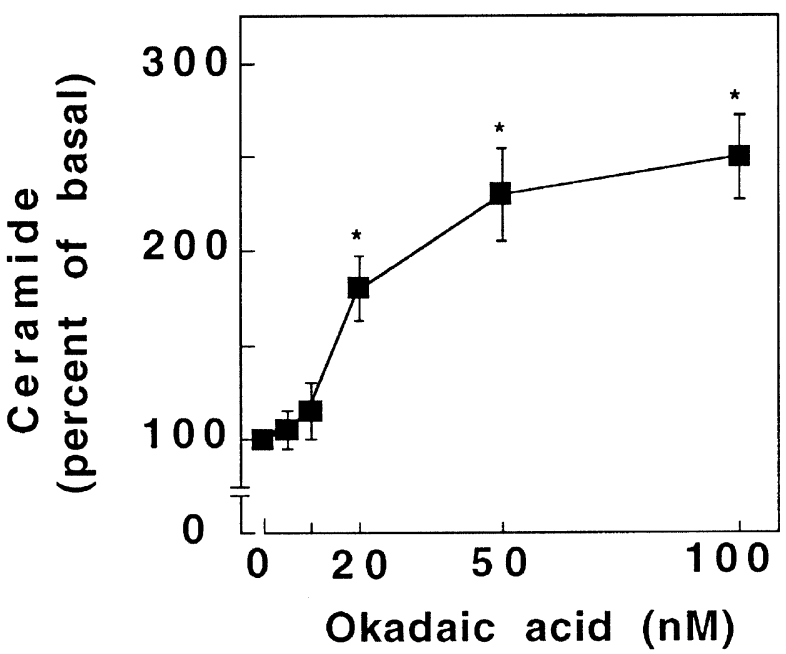

Figure 3 OA evokes ceramide accumulation. CHP-100 cells were labeled to equilibrium with $\left[{ }^{14} \mathrm{C}\right]$-palmitate $(1 \mu \mathrm{Ci} / \mathrm{ml})$ and then exposed to vehicle or $\mathrm{OA}$ at the indicated concentrations for $24 \mathrm{~h}$. Lipids were then extracted, subjected to mild alkaline hydrolysis, resolved by HPTLC as reported in the text and ceramide radioactivity determined. Results are means \pm S.D. of four different experiments. Statistical significance: ${ }^{*} P<0.01$, as compared to samples treated with carrier only, as from paired data analysis

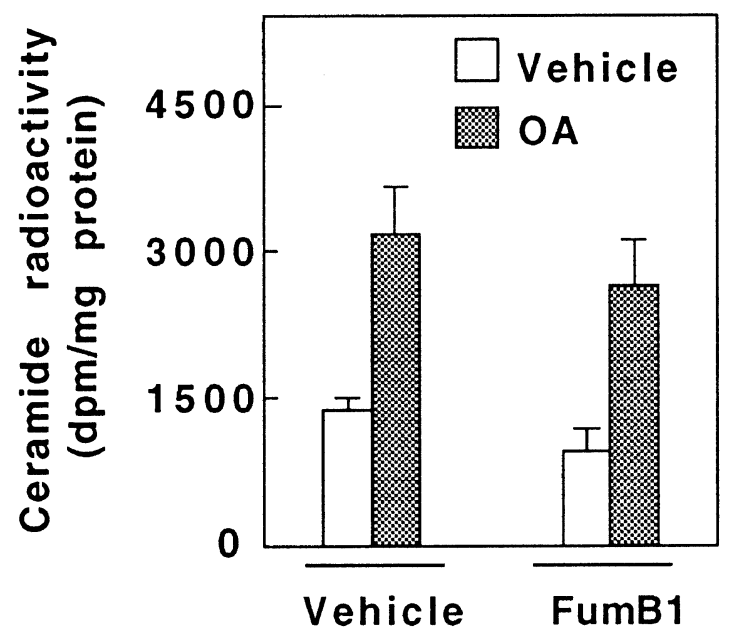

Figure 4 OA-evoked ceramide accumulation is not suppressed by fumonisin B1. $\left[{ }^{14} \mathrm{C}\right]$-Palmitate-labeled cells were incubated for $24 \mathrm{~h}$ with vehicle or $50 \mathrm{nM}$ $\mathrm{OA}$, either in the absence (Vehicle) or presence of $25 \mu \mathrm{M}$ fumonisin $\mathrm{B}_{1}$ (FumB1). Lipids were then extracted, subjected to mild alkaline hydrolysis, resolved by HPTLC as reported in the text and ceramide radioactivity determined. Results are means \pm S.D. of four different experiments generation may occur after activation of upstream caspases; ${ }^{21,22}$ to address this point in our system, CHP-100 cells were exposed to $50 \mathrm{nM} \mathrm{OA}$ and the kinetics of apoptosis induction, caspase activation and ceramide accumulation investigated. Figure 5 (upper panel) shows that the onset of apoptosis occurred after $5 \mathrm{~h}$ from OA administration and the phenomenon was fairly maximal by $15 \mathrm{~h}$; consistently with this result, caspase activation, as monitored by PARP cleavage, was not observed within $5 \mathrm{~h}$ (Figure 5, lower panel). Remarkably, the time-course of ceramide accumulation displayed a different profile; in fact, as shown in Figure 5 (upper panel), ceramide was substantially elevated already within $5 \mathrm{~h}$ from OA administration, namely prior to caspase activation and apoptosis onset. In keeping with the above mentioned results, ceramide elevation, as observed after $5 \mathrm{~h}$ of cell treatment with $50 \mathrm{nM} \mathrm{OA}$, was not affected by $100 \mu \mathrm{M}$ Z-VAD (not shown); however, upon prolonging cell treatment with $50 \mathrm{nM}$ OA to $24 \mathrm{~h}$, ceramide accumulation was reduced by a rough $50 \%$ by the presence of $100 \mu \mathrm{M}$ Z-VAD (Figure 6). Notably, Figure 6 shows that cell treatment for $24 \mathrm{~h}$ with $50 \mathrm{nM}$ OA increased glucosylceramide levels, thus indicating that, after production, ceramide partly undergoes metabolism
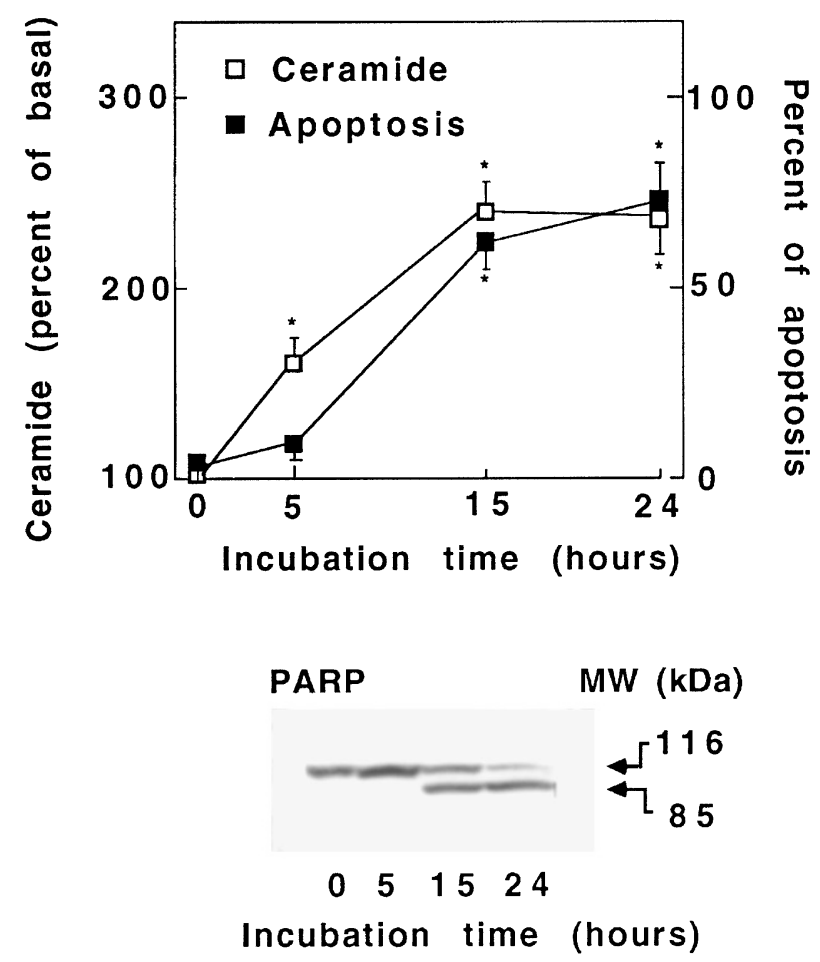

Figure 5 OA-induced ceramide accumulation precedes caspase activation and apoptosis. (Upper panel) $\left[{ }^{14} \mathrm{C}\right]$-Palmitate-labeled cells were incubated for the indicated times with vehicle or $50 \mathrm{nM} \mathrm{OA}$. Lipids were then extracted, subjected to mild alkaline hydrolysis, resolved by HPTLC as reported in the text and ceramide radioactivity determined. Treatment with $50 \mathrm{nM}$ OA for the indicated times was also performed on unlabeled cells that were then processed for apoptosis determination by flow cytometric analysis. Results are means \pm S.D. of four different experiments. Statistical significance: ${ }^{\star} P<0.01$, as compared to samples treated with carrier only, as from paired data analysis. (Lower panel) Cells were incubated for the indicated times with vehicle or $50 \mathrm{nM}$ OA and total lysates analyzed by Western blotting for PARP 


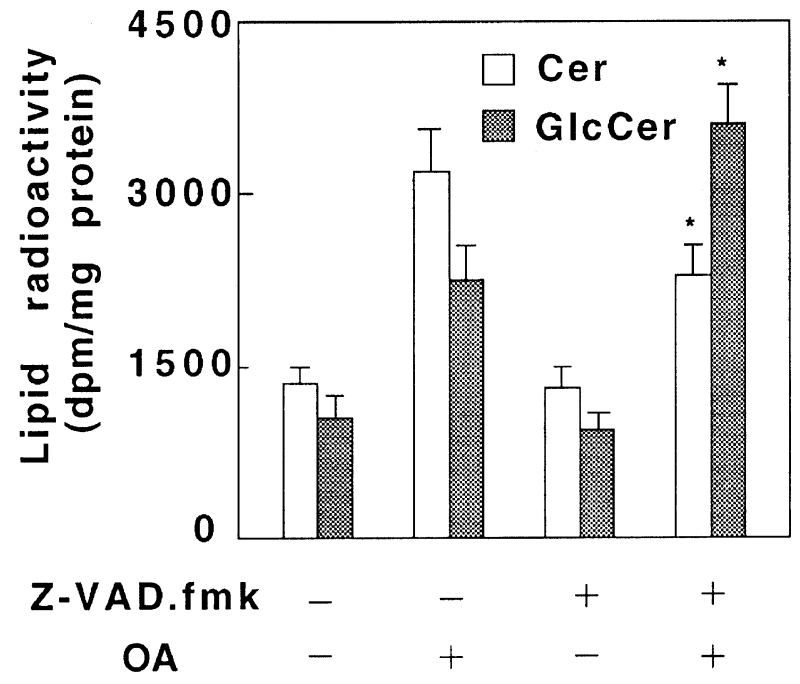

Figure 6 Z-VAD.fmk inhibits late ceramide accumulation evoked by OA but increases accumulation of glucosylceramide. $\left[{ }^{14} \mathrm{C}\right]$-Palmitate-labeled cells were incubated for $24 \mathrm{~h}$ with vehicle or $50 \mathrm{nM} O A$, either in the presence or absence of $100 \mu \mathrm{M}$ Z-VAD.fmk. Lipids were then extracted, subjected to mild alkaline hydrolysis resolved by HPTLC as reported in the text and radioactivity in ceramide (Cer) and glucosylceramide (GlcCer) determined. Presence or absence of OA or Z-VAD.fmk in the incubation media are indicated by ' + ' or '-', respectively. Results are means \pm S.D. of four different experiments. Statistical significance: ${ }^{*} P<0.01$, as from paired data analysis

through glucosylation; most remarkably, combined treatment with $50 \mathrm{nM}$ OA and $100 \mu \mathrm{M}$ Z-VAD.fmk did not impair but, indeed, elevated glucosylceramide levels (Figure 6).

\section{$\mathrm{OA}$, at concentrations eliciting cell death, does not} block the apoptotic effect of short-chain ceramide

It is well established that ceramide activates a PP2A, ${ }^{23,24}$ whose role in apoptosis is, however, ill-defined. Since PP2A are strongly inhibited by $\mathrm{OA}(\mathrm{Ki}=0.2 \mathrm{nM})^{8}$ and it has been mentioned that OA can prevent ceramide-induced apoptosis, ${ }^{25}$ we were prompted to investigate whether, in CHP-100 cells, the combined treatment with $\mathrm{N}$-hexanoyl sphingosine $\left(\mathrm{C}_{6}\right.$-Cer) and $\mathrm{OA}$ induced an apoptotic response higher or equal to that elicited by OA alone; in the latter case, in fact, any role for ceramide as a possible mediator of apoptosis induced by OA had to be dismissed. In the study, OA was employed at the concentrations of 10 or $20 \mathrm{nM}$; these concentrations, while expected to inhibit PP2A, did not cause per se extensive apoptosis, thus allowing evaluation of the contribution given to cell death by $\mathrm{C}_{6}$-Cer. As shown in Figure 7, $\mathrm{OA}$ did not inhibit $\mathrm{C}_{6}$-Cer-induced apoptosis; in fact, when cells were incubated for $24 \mathrm{~h}$ in media containing $30 \mu \mathrm{M}$ $\mathrm{C}_{6}$-Cer plus the PP inhibitor at the above-mentioned concentrations, the apoptotic response was fairly the sum of that elicited by short-chain ceramide and OA alone.

\section{Discussion}

We have reported that apoptosis induced by the PP inhibitor OA in CHP-100 cells is largely, albeit not completely, dependent on caspase activation; in addition, we have

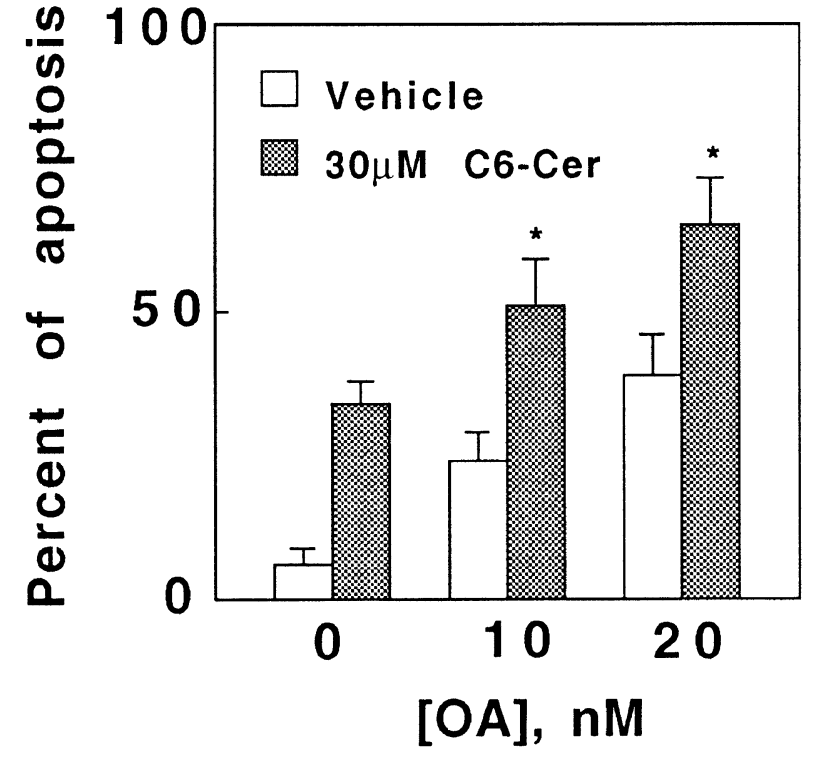

Figure 7 OA does not prevent short-chain ceramide-induced apoptosis CHP-100 cells were incubated for $24 \mathrm{~h}$ with vehicle or $30 \mu \mathrm{M} \mathrm{C}_{6}$-Cer, either in the absence or presence of $\mathrm{OA}$ at the indicated concentrations. Apoptosis was determined by flow cytometric analysis. Results are means \pm S.D. of four different experiments. Statistical significance: ${ }^{*} P<0.01$, as compared to samples treated with OA only, as from paired data analysis

shown that OA-induced and caspase-mediated apoptosis associates with elevation of intracellular ceramide levels. Ceramide has been suggested to provide a key lipid mediator in apoptosis, largely based on the evidence that various agents able to induce cell death also stimulate its accumulation and that administration of cell-permeant ceramides can reproduce the apoptotic response. Based on the observation that short-chain ceramide induces caspase-mediated apoptosis in CHP-100 cells, ${ }^{15}$ results herein reported raise the possibility that ceramide elevation may be involved in mediating the apoptotic response elicited by sustained PP inhibition. The relationships between ceramide accumulation and caspase activation have turned to be complex. Recently, it has been reported that sphingomyelinase-mediated ceramide generation occurring after receptor stimulation may be under the control of upstream caspases; ${ }^{21,22}$ in another study the role of ceramide in receptor-mediated apoptosis has been challenged and it has been suggested that ceramide accumulation is the consequence rather than the cause of activation of a death executioner caspase. ${ }^{26}$ In our system, OA induced ceramide elevation was already observed before PARP cleavage and apoptosis onset; at this time, lipid accumulation was also insensitive to the caspase inhibitor Z-VAD.fmk. However, as apoptosis progressed to completion, ceramide elevation was largely sustained by a mechanism that was sensitive to Z.VAD.fmk. While these results rule out the possibility that ceramide accumulation is a mere consequence of cell death, the question arises as to the mechanism(s) that drive late accumulation of the active lipid. We can not exclude that late ceramide accumulation occurs, at least in part, due to a caspase-mediated sphingomyelinase activation; however, since in OA-treated cells Z-VAD.fmk also 
elicited a marked elevation of glucosylceramide, the possibility holds that late ceramide accumulation might be sustained by block of its removal through glucosylation. This view may be in line with a recent report showing that caspasedependent downregulation of glucosylceramide synthase activity largely contributes to the kinetics and magnitude of ceramide elevation in tumor necrosis factor stimulated rhabdomyosarcoma cells. ${ }^{27}$ Moreover, it has been shown that the multidrug-resistant state of cancer cells may be associated with elevated glucosylceramide synthase activity and can be reversed by inhibition of ceramide glucosylation; ${ }^{28-30}$ thus, suppression of ceramide glucosylation might relevantly contribute to apoptosis propagation. Surprisingly enough, evidence for caspase involvement in cell death induced by sustained PP inhibition has, to date, seldomly been provided. In this respect, Morana and coworkers ${ }^{12}$ have reported that apoptosis induced by prolonged exposure of ML-1 leukemia cells to calyculin A associates with PARP cleavage; since apoptosis occurred in the setting of retinoblastoma protein shift to the hypophosphorylated state, the authors suggested that suppression of a retinoblastoma protein kinase activity could be involved in ICE/ CED3 protease activation. In a set of experiments that have not been shown we observed that retinoblastoma protein shift to the hypophosphorylated state (and protein downregulation, as well) also occurred in CHP-100 cells, in association with OA-evoked and caspase-mediated apoptosis. Intriguingly, retinoblastoma protein shift to the hypophosphorylated state was not observed in cells treated with $10 \mathrm{nM} \mathrm{OA} \mathrm{(not} \mathrm{shown).}$ Based on a previous report indicating that ceramide can elicit both retinoblastoma protein dephosphorylation and caspase activation, ${ }^{15}$ our results suggest that $\mathrm{OA}$-induced ceramide generation might be upstream of both phenomena. The mechanism through which $\mathrm{OA}$ elicits ceramide generation remains to be elucidated and might involve sphingomyelinase activation: in this respect, in fact, we have observed that fumonisin $B_{1}$, a potent inhibitor of ceramide neosynthesis was ineffective in blocking OA-induced ceramide accumulation and apoptosis. Moreover, since OA is a potent inhibitor of both $\mathrm{PP} 2 \mathrm{~A}$ and $\mathrm{PP} 1^{8}$ it remains to be established the contribution given by inhibition of the above mentioned PPS to ceramide generation. A result herein reported whose elucidation will also need further study is that $O A$, at the lower concentration tested (i.e. $10 \mathrm{nM}$ ), was able to induce apoptosis through a mechanism that was independent on ceramide production and caspase activation. Given the fact that control of protein phosphorylation provides a basic mechanism through which cell metabolism and functions are controlled, it is not unexpected that PP inhibitors might signal for apoptosis through multiple mechanisms that may depend on the pattern of the inhibited PPs and by the specific cell response.

\section{Materials and Methods}

\section{Materials}

CHP-100 human neuroepithelioma were obtained through the courtesy of Prof. G. Melino (University of Rome 'Tor Vergata', Italy). Material for cell culture was from Gibco BRL (MD, USA). OA and fumonisin $B_{1}$ were from Sigma Chemical Co. (St. Louis, MO, USA).
The anti-PARP mouse monoclonal antibody was from Biomol Res. Lab. (Plymouth Meeting, PA, USA); The anti-CPP32 rabbit polyclonal antibody was from Pharmingen (San Diego, CA, USA). Z-VAD.fmk was from Alexis Co. (San Diego, CA, USA). $\mathrm{C}_{6}$-Cer was from Calbiochem Novachem Co. (La Jolla, CA, USA). $\left[{ }^{14} \mathrm{C}\right]-P a l m i t i c$ acid $(55.3 \mathrm{mCi} / \mathrm{mmol})$ and the chemiluminescence $\mathrm{ECL}$ detection system were from Amersham Corp. (Bucks., UK). High-performance thin layer chromatography (HPTLC) silica gel 60 plates were from Merck (Darmstadt, Germany).

\section{Cell culture and apoptosis evaluation by flow cytometric analysis}

CHP-100 cells were grown at $37^{\circ} \mathrm{C}$ in RPMI-1640 medium, supplemented with $10 \%(\mathrm{v} / \mathrm{v})$ heat-inactivated fetal calf serum, $2 \mathrm{mM}$ glutamine, $100 \mathrm{i} . u . / \mathrm{ml}$ penicillin and $100 \mu \mathrm{g} / \mathrm{ml}$ streptomycin, in a humidified atmosphere with $5 \%(\mathrm{v} / \mathrm{v}) \mathrm{CO}_{2}$. Cell treatments were performed in complete growth medium. Apoptosis was monitored by evaluation of the pre- $G_{1}$ cell population, after flow cytometric analysis. Cells were detached from the plates by trypsin treatment and centrifuged at $300 \times g$ for $5 \mathrm{~min}$; pellets were washed with

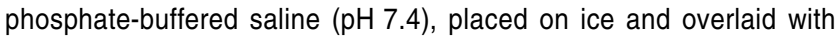
$0.5 \mathrm{ml}$ of a solution containing $50 \mu \mathrm{g} / \mathrm{ml}$ propidium iodide, $0.1 \%$ Triton $\mathrm{X}-100$ and $0.1 \%$ sodium citrate. After gentle resuspension in this solution cells were left at $4{ }^{\circ} \mathrm{C}$ for 30 min at least, in the absence of light, before analysis. Propidium iodide-stained cells were analyzed using a FACScan Flow Cytometer (Beckton-Dickinson, CA, USA); fluorescence was measured between 565 and $605 \mathrm{~nm}$. The data were acquired and analyzed by the Lysis II program (Becton-Dickinson, CA, USA).

\section{Western blotting}

Cells were washed with phosphate-buffered saline $(\mathrm{pH} 7.4)$ and lysed in $62 \mathrm{mM}$ Tris- $\mathrm{HCl}$ pH 6.8, containing 2\% SDS, $2 \mathrm{mM}$ EDTA, $20 \mu \mathrm{g} / \mathrm{ml}$ aprotinin, $10 \mu \mathrm{g} / \mathrm{ml}$ leupeptin, $1 \mathrm{mM}$ phenylmethylsulfonyl fluoride and $1 \mathrm{mM}$ sodium vanadate. After sonication aliquots of lysates were saved for protein determination ${ }^{31}$ and, after addition of $0.05 \% \beta$ mercaptoethanol, samples were boiled for $10 \mathrm{~min}$. Proteins from cell lysates $(40 \mu \mathrm{g})$ were resolved by SDS-PAGE, transferred overnight at $25 \mathrm{~mA}$ onto nitrocellulose paper and analyzed by Western blot as previously described. ${ }^{32} \mathrm{ECL}$ detection was performed according to the manufacturer's instructions.

\section{Cell labeling with $\left[{ }^{14} \mathrm{C}\right]$-palmitate, lipid extraction and separation}

Cells grown in $35 \mathrm{~mm}$ plates were labeled with $\left[{ }^{14} \mathrm{C}\right]$-palmitic acid $(1 \mu \mathrm{Ci} / \mathrm{ml})$ for $24 \mathrm{~h}$. After washing with RPMI plus $0.1 \%$ bovine serum albumin, cells were reincubated for $24 \mathrm{~h}$ in label free growth medium prior to any treatment. Lipids were extracted according to ${ }^{33}$ and subjected to mild alkaline hydrolysis with $0.1 \mathrm{M}$ methanolic $\mathrm{KOH}$ for $1 \mathrm{~h}$ at $30^{\circ} \mathrm{C}$. After re-extraction, the chloroformic phase was analyzed by HPTLC. Ceramide and glucosylceramide separation was achieved by developing samples in $n$-hexane/diethylether/acetic acid $(25: 75: 1$, $\mathrm{vol} / \mathrm{vol}$ ) for full plate height, followed by development in the same direction in chloroform/methanol/0.7 $\mathrm{N} \mathrm{NH}_{4} \mathrm{OH}(20: 5: 0.5$, vol/vol), up to $3 \mathrm{~cm}$ from the top, and again in the same direction in $\mathrm{n} /$ hexane/ diethylether/acetic acid (25:75:1, vol/vol) for full plate height. ${ }^{17}$ Lipids were visualized under iodine and spots scraped off from the plates into counting vials for radioactivity determination. Radiometric estimation of changes in ceramide levels was confirmed by gas-chromatographic analysis, as previously reported. ${ }^{17}$ 


\section{Acknowledgements}

This work was partially supported by grants: AIRC, Italian Ministry of University and Scientific Technological Research and Ministry of Health "Ricerca Corrente".

\section{References}

1. Boe R, Gjertsen BT, Vintermyr OK, Houge G, Lanotte M and Doskeland SO (1991) The protein phosphatase inhibitor okadaic acid induces morphological changes typical of apoptosis in mammalian cells. Exp. Cell Res. 195: 237-246

2. Meikrantz W, Gisselbrecht S, Tam SW and SchlegelR (1994) Activation of cyclin A-dependent protein kinases during apoptosis. Proc. Natl. Acad. Sci. USA 91: 3754-3758

3. Sheikh MS, Garcia M, Zhan Q, Li Y and Fornace AJ Jr (1996) Cell cycleindependent regulation of p21Waf1/Cip1 and retinoblastoma protein during okadaic acid-induced apoptosis is coupled with induction of Baxprotein in human breast carcinoma cells. Cell Growth Differ. 7: 1599-1607

4. Benito A, Lerga A, Silva M, Leon J and Fernandez-Luna JL (1997) Apoptosis of human myeloid cells induced by an inhibitor of protein phosphatases (okadaic acid) is prevented by $\mathrm{Bcl}-2$ and $\mathrm{Bcl}-\mathrm{X}_{\mathrm{L}}$. Leukemia 11: 940-944

5. Morimoto Y, Ohba T, Kobayashi S and Haneji T (1997) The protein phosphatase inhibitors okadaic acid and calyculin $\mathrm{A}$ induce apoptosis in human osteoblastic cells. Exp. Cell Res. 230: 181-186

6. Li DW, Fass U, Huizar I and Spector A (1998) Okadaic acid-induced lens epithelial cell apoptosis requires inhibition of phosphatase-1 and is associated with induction of gene expression including p53 and bax. Eur. J. Biochem. 257: $351-361$

7. Nuydens R, de Jong M, Van Den Kieboom G, Heers C, Dispersyn G, Cornelissen F, Nuyens R, Borgers M and Geerts H (1998) Okadaic acid-induced apoptosis in neuronal cells: evidence for an abortive mitotic attempt. J. Neurochem. 70: $1124-1133$

8. Wera S and Hemmings BA (1995) Serine/threonine protein phosphatases. Biochem. J. 311: 17-29

9. Ghosh S, Schroeter D and Paweletz N (1996) Okadaic acid overrides the Sphase check point and accelerates progression of $\mathrm{G}_{2}$-phase to induce premature mitosis in HeLa cells. Exp. Cell Res. 227: 165-169

10. Ludlow JW, Glendening CL, Livingstone DM and DeCaprio JA (1993) Specific enzymatic dephosphorylation of the retinoblastoma protein. Mol. Cell. Biol. 13: $367-372$

11. Riordan FA, Foroni L, Hoffbrand AV, Mehta AB and Wickremasinghe RG (1998) Okadaic acid-induced apoptosis of HL60 leukemia cells is preceded by destabilization of bcl-2 mRNA and downregulation of bcl-2 protein. FEBS Lett. 435: $195-198$

12. Morana SJ, Wolf CM, Li J, Reynolds JE, Brown MK and Eastman A (1996) The involvement of protein phosphatases in the activation of ICE/CED-3 protease, intracellular acidification, DNA digestion, and apoptosis. J. Biol. Chem. 271: $18263-18271$

13. Hannun YA (1996) Functions of ceramide in coordinating cellular responses to stress. Science 274: 1855-1859

14. Mathias S, Peña LA and Kolesnick RN (1998) Signal transduction of stress via ceramide. Biochem. J. 335: 465-480

15. Spinedi A, Amendola A, Di Bartolomeo S and Piacentini M (1998) Ceramideinduced apoptosis is mediated by caspase activation independently from retinoblastoma protein post-translational modification. Biochem. Biophys. Res. Commun. 243: 852-857
16. Cohen GM (1997) Caspases: the executioners of apoptosis. Biochem. J. 326 $1-16$

17. Spinedi A, Di Bartolomeo S and Piacentini M (1998) Apoptosis induced by Nhexanoylsphingosine in CHP-100 cells associates with accumulation of endogenous ceramide and is potentiated by inhibition of glucocerebroside synthesis. Cell Death Differ. 5: 785-791

18. Bose R, Verheij M, Haimovitz-Friedman A, Scotto K, Fuks Z and Kolesnick R (1995) Ceramide synthase mediates daunorubicin-induced apoptosis: an alternative mechanism for generating death signals. Cell 82: 405-414

19. Xu J, Yeh C-H, Chen S, He L, Sensi SL, Canzoniero LMT, Choi DW and Hsu CY (1998) Involvement of de novo ceramide biosynthesis in tumor necrosis factor- $\alpha$ / cycloheximide-induced cerebral endothelial cell death. J. Biol. Chem. 273: $16521-16526$

20. Wieder T, Orfanos CE and Geilen CC (1998) Induction of ceramide-mediated apoptosis by the anticancer phospholipid analog, hexadecylphosphocholine. J. Biol. Chem. 273: 11025-11031

21. Dbaibo GS, Perry DK, Gamard CJ, Platt R, Poirier GG, Obeid LM and Hannun YA (1997) Cytokine response modifier A (CrmA) inhibits ceramide formation in response to tumor necrosis factor (TNF)- $\alpha$ : CrmA and Bcl-2 target distinct components in the apoptotic pathway. J. Exp. Med. 185: 481-490

22. Genestier L, Prigent A-F, Paillot R, Quemeneur L, Durand I, Banchereau J, Revillard JP and Bonnefoy-Bérard N (1998) Caspase-dependent ceramide production in Fas- and HLA Class I-mediated peripheral T cell apoptosis. J. Biol. Chem. 273: 5060-5066

23. Dobrowsky RT, Kamibayashi C, Mumby MC and Hannun YA (1993) Ceramide activates heterotrimeric protein phosphatase 2A. J. Biol. Chem. 268: 1552315530

24. Wolff RA, Dobrowsky RT, Bielawska A, Obeid LM and Hannun YA (1994) Role of ceramide-activated protein phosphatase in ceramide-mediated signal transduction. J. Biol. Chem. 269: 19605-19609

25. Hannun YA(1994) The sphingomyelin cycle and the second messenger function of ceramide. J. Biol. Chem. 269: 3125-3128

26. Gamen S, Anel A, Piñeiro A and Naval J (1998) Caspases are the main executioners of Fas-mediated apoptosis, irrespective of the ceramide signalling pathway. Cell Death Differ. 5: 241-249

27. Bourteele S, Haußer A, Döppler H, Horn-Müller J, Röpke C, Schwarzmann G, Pfizenmaier K and Müller G (1998) Tumor necrosis factor induces ceramide oscillations and negatively controls sphingolipid synthases by caspases in apoptotic Kyn-1 cells. J. Biol. Chem. 273: 31245-31251

28. Lavie Y, Cao H, Bursten SL, Giuliano AE and Cabot MC (1996) Accumulation of glucosylceramides in multidrug-resistant cancer cells. J. Biol. Chem. 271 $19530-19536$

29. Lavie Y, Cao H, Volner A, Lucci A, Han T-Y, Geffen V, Giuliano AE and Cabot MC (1997) Agents that reverse multidrug resistance, tamoxifen, verapamil, and cyclosporin A, block glycosphingolipid metabolism by inhibiting ceramide glycosylation in human cancer cells. J. Biol. Chem. 272: 1682-1687

30. Liu Y-Y, Han T-Y, Giuliano AE and Cabot MC (1999) Expression of glucosylceramide synthase, converting ceramide to glucosylceramide, confers adriamycin resistance in human breast cancer cells. J. Biol. Chem. 274: 11401146

31. Lowry OH, Rosebrough NJ, Farr AL and Randall RJ (1951) Protein measurement with the Folin phenol reagent. J. Biol. Chem. 193: 265-275

32. Melino G, Annicchiarico-Petruzzelli M, Piredda L, CandiE, Gentile V, Davies PJA and Piacentini M (1994) 'Tissue' transglutaminase and apoptosis: sense and antisense transfection studies in human neuroblastoma cells. Mol. Cell. Biol. 14: $6584-6596$

33. Bligh EC and Dyer WJ (1959) A rapid method for total lipid extraction and purification. Can. J. Biochem. Physiol. 37: 911-917 